HUNGARIAN AGRICULTURAL ENGINEERING

N³7/2020 97-

Published online: http://hae-journals.org/

HU ISSN 0864-7410 (Print) / HU ISSN 2415-9751(Online)

DOI: 10.17676/HAE.2020.37.97

Received: 11.11.2019 - Accepted: 15.02.2020
PERIODICAL OF THE COMITTEE OF

AGRICULTURAL AND BIOSYSTEM

ENGINEERING OF

THE HUNGARIAN ACADEMY OF SCIENCES

and

SZENT ISTVÁN UNIVERSITY

Faculty of Mechanical Engineering

\title{
MONITORING OF DIFFERENT PROBIOTIC ACTIVITY LACTOBACILLUS STRAINS' GROWTH BY DIFFERENT PHYSICO-CHEMICAL PARAMETERS
}

\author{
Author(s): \\ T. Kaszab ${ }^{1}$, Zs. Bodor ${ }^{1}$, Cs. Mohácsi-Farkas ${ }^{2}$, A. Slavchev³ and Z. Kovacs ${ }^{1}$
}

\section{Affiliation:}

${ }^{1}$ Department of Physics and Control, Faculty of Food Science, Szent István University

Somlói út 14-16., Budapest, $\mathrm{H}-1118$, Hungary

2Department of Microbiology and Biotechnology, Faculty of Food Science, Szent István University

Somlói út 14-16., Budapest, H-1118, Hungary

3University of Food Technologies, Department of Microbiology, 26 "Maritza" Blvd., 4002 Plovdiv, Bulgaria

\section{Email address:}

Kaszab.Timea@etk.szie.hu, Mohacsine.Farkas.Csilla@etk.szie.hu

\begin{abstract}
Lactic acid bacteria (LABs) are Gram+, anaerobic or facultative anaerobic bacteria requiring specific nutrition environment whose major metabolite end product is lactic acid. The aim of our study was to describe the behaviour of the different bacteria strains during the yoghurt fermentation by various microbiological, physical and chemical methods. The formation of the yoghurt character was monitored for 20 hours at $37^{\circ} \mathrm{C}$ by viscosity and $\mathrm{pH}$ measurement methods. The tested physical and chemical properties of the yogurt samples prepared presented high variability which can be useful in the product development of probiotic yogurt.
\end{abstract}

Keywords: yoghurt, Lactobacillus, viscosity, $\mathrm{pH}$

\section{Introduction}

Lactic acid bacteria (LABs) are non-pathogenic, Gram+ bacteria with anaerobic of facultative anaerobic metabolism. They require specific nutritional environment and the end product of their metabolism is lactic acid (Slavchev et al., 2015).

LABs are commonly associated with the human gastrointestinal tract (GIT), due to their beneficial effect on digestion and physical condition (Remagnia et al., 2013). The industrial importance of LABs is given by their fermentation activity and nutritional advantage originating from their probiotic activity. Probiotics have numerous beneficial attributes in health such as supporting the immune system, decreasing risk of colon cancer, decrease the symptoms of lactose intolerance and relieve irritable bowel syndrome. The most important property of probiotics is that they can survive in the upper gastrointestinal tract despite the low $\mathrm{pH}$ (Slavchev et al., 2017).

The demand for probiotic containing food has increased recently (Michael et al., 2015). Yoghurt is known as the most popular carrier for probiotic bacteria (Fazilah et al., 2018). Yoghurt is a dairy product produced from mammalian milk such as cow, goat, buffalo, or sheep. In the industry cow milk is the most commercial, it is produced by the inoculation of milk with the starter culture after setting fat content and homogenization. The starter culture usually contain Streptococcus thermophilus and Lactobacillus delbrueckii subsp. bulgaricus strains (Tamime \& Robinson, 2010).

L. delbrueckii subsp. bulgaricus and S. thermophilus were obtained in fermented milk product and in gel by rotational viscosity measurements were made with a coaxial cylinder Rotovisco RV2 reometer at $25^{\circ} \mathrm{C}$. Viscosity was measured before and after stirring to test the resistance of the yogurt to mechanical handling. For that, yogurts were stirred on a magnetic stirrer for $1 \mathrm{~min}$, and viscosity was measured thereafter. The viscosities measured after stirring were lower than those measured before stirring. In comparison, the 
viscosities of milks fermented with the S. thermophilus single-strain cultures increased only slightly and reached values of only $100 \mathrm{mPas}$. The gels were lumpy, and syneresis was apparent. The chemically acidified gel was fragile and reached a viscosity of only $90 \mathrm{mPas}$ at $\mathrm{pH} 4.0$, which is close to values obtained with the nonproducing strains. The stirring technique cannot be compared with industrial conditions, and, therefore, conclusions cannot be drawn for yogurt manufacture, but the comparison of viscosities measured before and after stirring is nonetheless instructive (Bouzar et al, 1997).

Afonso and Maia (1999) studied the rheological changes of the yoghurt at different point in the manufacturing process and to try to gain some measure of understanding of the morphological changes that occur. Development of structure during manufacture of stirred yoghurt was measured in shear rate sweep mode by oscillatory rheometer. The structural and rheological changes that occurred during post-incubation stages were observed during the analysis of cooled stirred yoghurt, stirred yoghurt with fruit and final stirred yoghurt samples after $3 \mathrm{~h}$ incubation time, confirming that strong structural degradation occurs as shear forces are increased.

The aim of our study was to describe the behaviour of the different bacteria strains during the yoghurt fermentation by various microbiological, physical and chemical methods. Furthermore aim was to discriminate bacteria with different probiotic activity using with above mentioned method.

\section{Materials and methods}

\section{Materials}

In this study 15 different bacterial strains (genus Lactobacillus bulgaricus) were analyzed. These strains can be divided into three main groups based on their probiotic activity: non-probiotic, moderately probiotic and probiotic based on their standard microbiological properties (Table 1).

Table 1. Selected Lactobacillus bulgaricus bacterial strains (Slavchev et al, 2015 and Slavchev et al, 2017)

\begin{tabular}{|c|c|c|c|c|c|}
\hline Strains & $\begin{array}{c}\text { Maximal } \\
\text { growth rate } \\
\left(\mu_{\max }\right) \text { in MRS } \\
\text { broth, } \mathrm{h}^{-1}\end{array}$ & $\begin{array}{c}\text { Maximal } \\
\text { optical density } \\
(\lambda=665 \mathrm{~nm}) \text { in } \\
\text { MRS broth }\end{array}$ & $\begin{array}{l}\text { MIC of } \\
\text { Bile, } \\
\mathrm{mg} / \mathrm{ml}\end{array}$ & $\begin{array}{c}\text { Yield of biomass } \\
\text { after } 3 \mathrm{~h} \text { stay at pH } \\
1.80 \text { and } 9000 \mathrm{U} / \mathrm{ml} \\
\text { pepsin }\end{array}$ & $\begin{array}{l}\text { Strain's } \\
\text { group }\end{array}$ \\
\hline R1 & $0.07 \pm 0.012$ & $1.676 \pm 0.046$ & 1.250 & $0.036 \pm 0.004$ & \multirow{5}{*}{$\begin{array}{c}\text { Probiotic } \\
\text { strains }\end{array}$} \\
\hline S06 & $0.301 \pm 0.012$ & $2.960 \pm 0.075$ & 1.250 & $0.080 \pm 0.010$ & \\
\hline S10 & $0.115 \pm 0.012$ & $2.950 \pm 0.075$ & 2.500 & $0.126 \pm 0.014$ & \\
\hline S11 & $0.118 \pm 0.013$ & $2.950 \pm 0.066$ & 2.500 & $0.100 \pm 0.014$ & \\
\hline S22 & $0.106 \pm 0.012$ & $2.677 \pm 0.092$ & 2.500 & $0.117 \pm 0.016$ & \\
\hline S01 & $0.121 \pm 0.011$ & $1.692 \pm 0.058$ & 0.625 & $0.038 \pm 0.010$ & \multirow{5}{*}{$\begin{array}{l}\text { Moderate } \\
\text { strains }\end{array}$} \\
\hline S07 & $0.075 \pm 0.012$ & $1.919 \pm 0.068$ & 0.625 & $0.049 \pm 0.013$ & \\
\hline S08 & $0.08 \pm 0.010$ & $2.940 \pm 0.093$ & 0.625 & $0.049 \pm 0.007$ & \\
\hline S09 & $0.118 \pm 0.017$ & $2.880 \pm 0.081$ & 0.156 & $0.029 \pm 0.005$ & \\
\hline Y12 & $0.150 \pm 0.027$ & $2.023 \pm 0.074$ & 0.625 & $0.041 \pm 0.006$ & \\
\hline S02 & $0.070 \pm 0.011$ & $1.521 \pm 0.035$ & 0.156 & $0.006 \pm 0.001$ & \multirow{5}{*}{$\begin{array}{l}\text { Non- } \\
\text { probiotic } \\
\text { strains }\end{array}$} \\
\hline S03 & $0.060 \pm 0.009$ & $1.343 \pm 0.039$ & 0.313 & $0.005 \pm 0.002$ & \\
\hline S04 & $0.060 \pm 0.012$ & $0.841 \pm 0.046$ & 0.156 & $0.007 \pm 0.002$ & \\
\hline S29 & $0.060 \pm 0.010$ & $1.440 \pm 0.046$ & 0.625 & $0.005 \pm 0.002$ & \\
\hline S30 & $0.050 \pm 0.011$ & $1.360 \pm 0.065$ & 0.625 & $0.006 \pm 0.002$ & \\
\hline
\end{tabular}

\section{Strain suspension}

Skimmed milk powder was diluted to reach $3.5 \%$ protein content from reconstituted milk with sterilized distilled water and inoculated with the freeze-dried monoculture bacteria. $10 \mathrm{mg}$ of freeze-dried bacteria was weighted in and filled up to $10 \mathrm{ml}$ with the reconstituted milk. This strain suspension was cultivated for 24 hours at $37^{\circ} \mathrm{C}$ to produce activated bacteria suspension. 


\section{Reconstituted milk product}

The reconstituted milk product was inoculated with this activated bacteria suspension to have initial cell number of $104 / \mathrm{ml}$ milk. This suspension was incubated for 11 hours at $37^{\circ} \mathrm{C}$ to produce yogurt and the cell count was determined at 4th and 11th hours of incubation by Breed Staining Method. The cell count was determined after the activation of bacteria and at the mentioned measurement times with three parallel measurements by layered plating method on MRS agar. For the plates 10 times dilution was prepared in six steps. The plates were incubated for 72 hours at $37^{\circ} \mathrm{C}$.

\section{Methods}

The formation of the yoghurt character was monitored for 20 hours at $37^{\circ} \mathrm{C}$ by viscosity and $\mathrm{pH}$ measurement methods. The $\mathrm{pH}$ value was detected with Mettler Toledo Seven Multi $\mathrm{pH}$ meter in every four minutes and resulted in $300 \mathrm{pH}$ values for each yoghurt product.

Viscosity of the yogurt formation was monitored by Haake RotoViscol rotational rheometer at 2 1/s maximal angular velocity. The shear stress was detected in every 5 seconds and resulted in 14400 data values for each yoghurt sample.

In case of each yoghurt formation the determined and calculated parameters were as the follows: inflection point of $\mathrm{pH}$ curve, $\mathrm{pH}$ values and viscosity at 4 th and 11 th hours, maximum value of the viscosity, the time at the maximum point of the viscosity and viscosity at the time of $\mathrm{pH}$ inflection point. The relative cell number was determined based on the change in cell number relative to initial cell number at 4 and 11 hours. The calculated relative cell number shows how many times larger increased the cell number since the beginning of experiment. Significant different was investigated by ANOVA test and Tukey HSD test.

\section{Results and discussion}

The Figure 1. shows the relative cell numbers at 4 hours and 11 hours relative to the initial cell numbers in case of probiotic, moderately probiotic and non-probiotic bacteria strains.
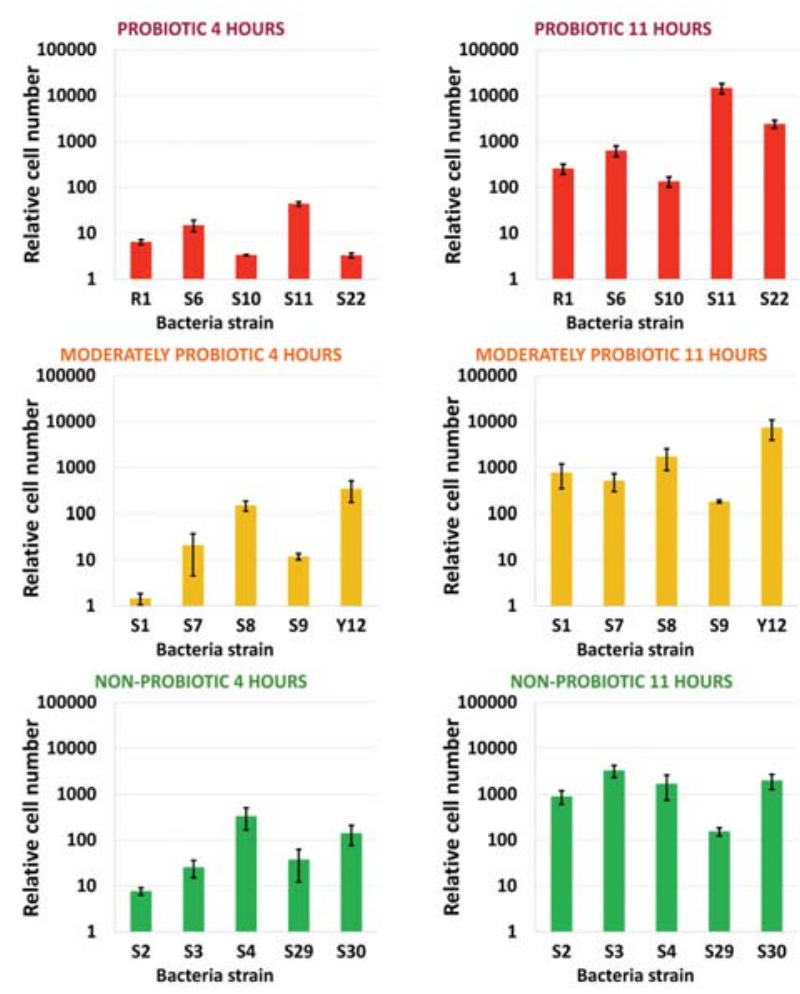

Figure 1. Relative cell numbers of the 15 different Lactobacillus bulgaricus bacteria strains at 4 and 11 hours 
The figure contains the average and standard deviation of the three parallel measurements in the case of the cell numbers. Cell numbers increased during the incubation time, those reached the cell number from the initial $103-104$ scale up to the $108-109$ scale. However, the samples show some deviations within the groups. The largest difference was observed among the different strain of moderately probiotic group, and the lowest one among the different strain of probiotic group based on cell number.

Some differences were found between the cell numbers at 4 and 11 hours, furthermore differences was found between the probiotic, moderately probiotic and non-probiotic groups. Significant differences was found between the average relative cell numbers at 4 hours. The Figure 2 shows the average value of the bacterial strain groups at 4 and 11 hours. The rate of the cell multiplication was the largest in the case of the probiotic group between the 4 and 11 hours, furthermore this group showed the largest cell numbers at the end of the experiment.
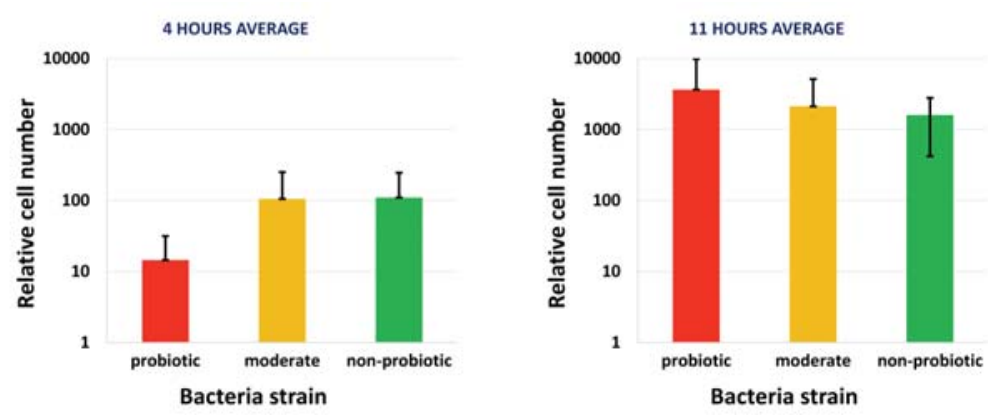

Figure 2. Group average of the relative cell numbers of Lactobacillus bulgaricus strains at 4 and 11 hours

The $\mathrm{pH}$ values were detected during the formation of the yoghurt. Line chart was represented from the recorded points, and the inflection point was determined according to article of Torrestiana et al. (1994). The Figure 3 shows the $\mathrm{pH}$ inflection points of the 15 bacterial strain samples.

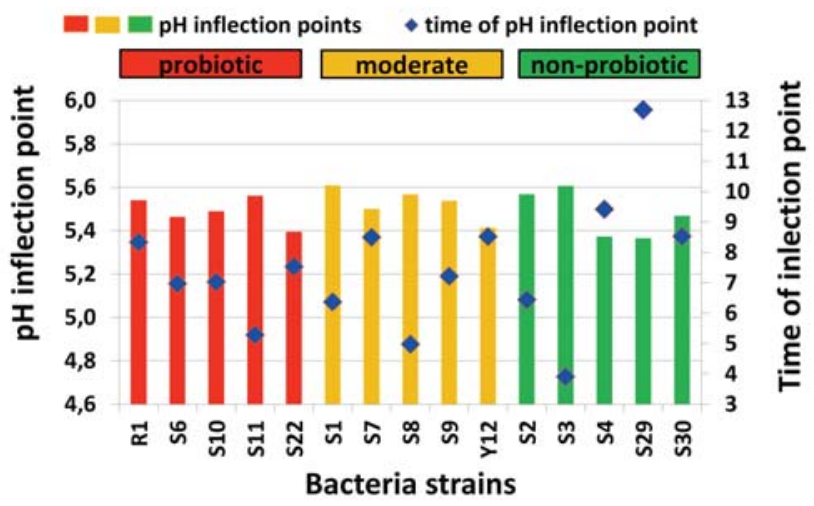

Figure 3. The $\mathrm{pH}$ inflection points of the different Lactobacillus bulgaricus strains

The Figure 3 shows the $\mathrm{pH}$ and time values at the inflection point. Weak differences were found between the bacteria groups, however the differences are larger within groups than between groups. The time of the inflection point showed the largest standard deviation in case of the non-probiotic group.

The average $\mathrm{pH}$ and time values at the inflection point can be seen on the right side of Figure 4. This diagram shows the average of the samples. Significant difference was not found between the groups.

The viscosity values were determined from the flow curve at 4 and 11 hours and at the time of $\mathrm{pH}$ inflection point. The Figure 5 shows these values in the case of the bacteria strain groups. The results of viscosity showed differences between the probiotic, moderately probiotic and non-probiotic groups. The viscosity values were the largest at 4 hours for the most of the samples. With the exception of S3, non-probiotic samples had the highest viscosity, while probiotics had the lowest viscosity. 


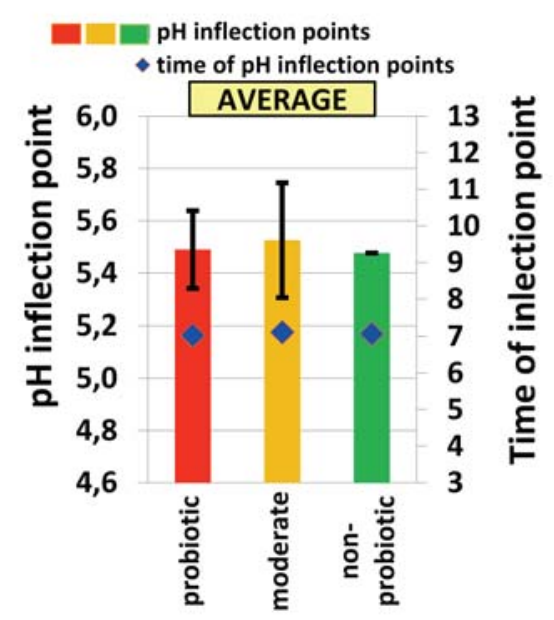

Figure 4. The $\mathrm{pH}$ inflection points of the bacteria strains

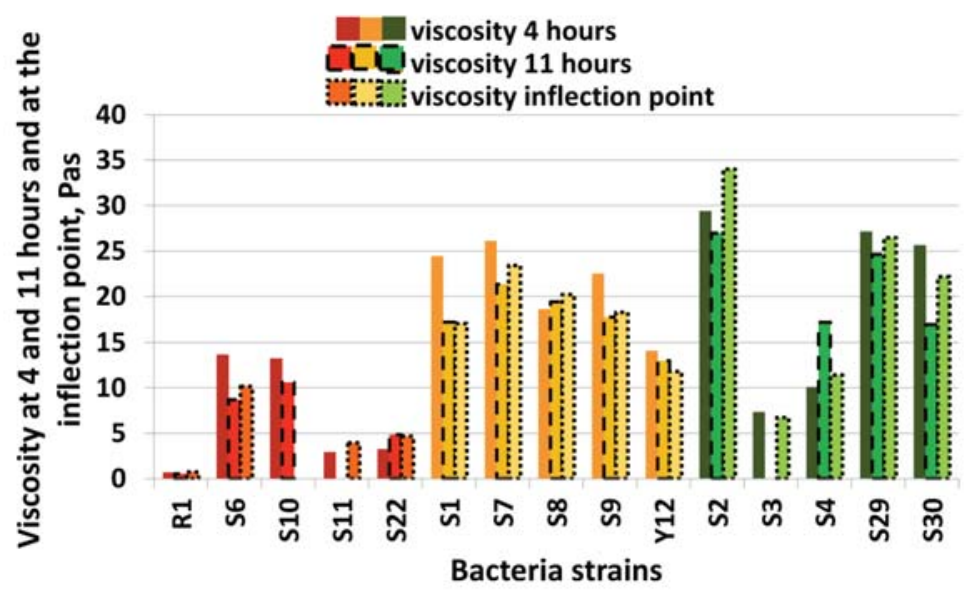

Figure 5. Viscosity at 4 and 11 hours and at the time of $\mathrm{pH}$ inflection point

The Figure 6 shows the average values of the viscosity of the probiotic, moderately probiotic and nonprobiotic groups. Significant difference was not found between the viscosity at 4 and 11 hours and the time of $\mathrm{pH}$ inflection point. The standard deviation of the non-probiotic group was the largest, while the moderate group had the lowest one.

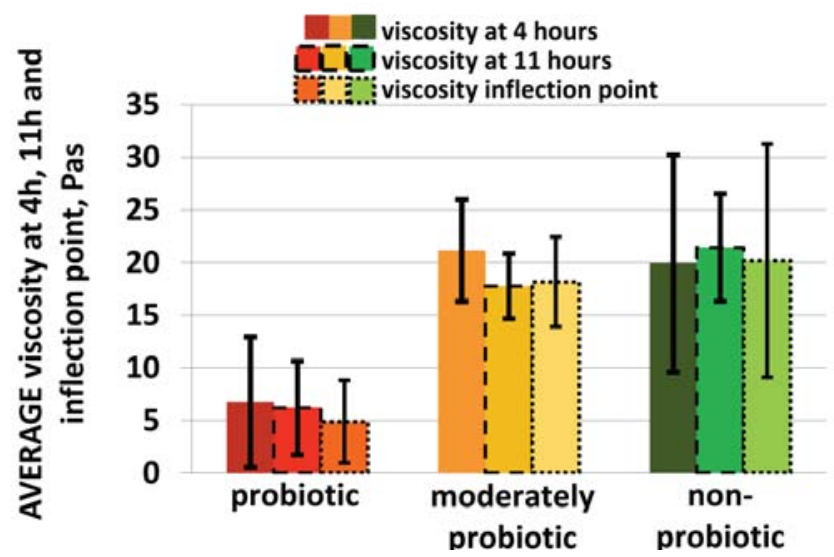

Figure 6. Average viscosity at 4 and 11 hours and at the time of $\mathrm{pH}$ inflection point 
Significant differences were found between the probiotic, moderately probiotic and non-probiotic groups based on viscosity values at 4 and 11 hours, furthermore at the time of $\mathrm{pH}$ inflection point. The probiotic group is significant different from the other two.

\section{Conclusions}

Different bacterial strains showed variable behavior properties in each measured parameter. According to the probiotic activity the cell number and the viscosity parameters showed significant difference. The variability of the strains shows that there is an industrial meaning of which strain is used for the yoghurt production, so our result can be useful to find the most appropriate strains for starter cultures. The tested physical and chemical properties of the yogurt samples prepared presented high variability which can be useful in the product development of probiotic yoghurt.

\section{Acknowledgements}

Supported by the Doctoral School of Food Science, Szent István University (Zsanett Bodor). This paper was supported by the János Bolyai Research Scholarship of the Hungarian Academy of Sciences. (Zoltán Kovács)

\section{References}

[1] Afonso, I. M and Maia, J. M. (1999) Rheological monitoring of structure evolution and development in stirred yoghurt. Journal of Food Engineering 42 (1999) $183 \pm 190$

[2] Bouzar F., Cerning, J. and Desmazeaud M. (1997). Exopolysaccharide Production and TexturePromoting Abilities of Mixed-Strain Starter Cultures in Yogurt Production. Journal of Dairy Science Vol. 80, No. 10, 1997

[3] Fazilah, N. F., Ariff, A. B., Khayat, M. E., Rios-Solis, L., and Halim, M. (2018). Influence of probiotics, prebiotics, synbiotics and bioactive phytochemicals on the formulation of functional yogurt. Journal of Functional Foods, 48(April), 387-399. https://doi.org/10.1016/j.jff.2018.07.039

[4] Michael, M., Phebus, R. K., and Schmidt, K. A. (2015). Plant extract enhances the viability of Lactobacillus delbrueckii subsp. bulgaricus and Lactobacillus acidophilus in probiotic non-fat yogurt. Food Science \& Nutrition, 3(1), 48-55. https://doi.org/10.1002/fsn3.189

[5] Remagnia, M. C., Moritab, H., Koshibab, H., Cattaneoc P. T. M. and Tsenkova R. (2013). Evaluation of Digestion Resistance of Lactic Acid Bacteria Using Near-infrared Spectroscopy and Aquaphotomics. In NIR 2013 - 16th International Conference on Near Infrared Spectroscopy (pp. 602-608). La Grande-Motte.

[6] Slavchev, A., Kovacs, Z., Koshiba, H., Nagai, A., Bázár, G., Krastanov, A., Kubota, Y. and Tsenkova, R. (2015). Monitoring of Water Spectral Pattern Reveals Differences in Probiotics Growth When Used for Rapid Bacteria Selection. PLOS ONE, 10(7), e0130698. https://doi.org/10.1371/journal.pone.0130698

[7] Slavchev, A., Kovacs, Z., Koshiba, H., Bazar, G., Pollner, B., Krastanov, A., \& Tsenkova, R. (2017). Monitoring of water spectral patterns of lactobacilli development as a tool for rapid selection of probiotic candidates. Journal of Near Infrared Spectroscopy, 25(6), 423-431. https://doi.org/10.1177/0967033517741133

[8] Tamime, A. Y., \& Robinson, R. K. (2010). Traditional and recent developments in yoghurt production and related products. In Tamime and Robinson's Yoghurt (pp. 348-467). Woodhead Publishing. https://doi.org/10.1533/9781845692612.348

[9] Torrestiana, B. S., Brito de la Fuente, E., Lacroix, C. and Choplin, L. (1994) Modelling the acidifying activity profile of Lactobacillus bulgaricus cultures. Applied Microbiology and Biotechnology 42:192-196 